\title{
Tomato chlorotic spot virus in Hydroponically-Grown Lettuce in São Paulo State, Brazil
}

\author{
Addolorata Colariccio, Marcelo Eiras, Alexandre L. R. Chaves, Ricardo Harakava \& César M. Chagas \\ Instituto Biológico, Av. Conselheiro Rodrigues Alves, 1252, CEP 04014-002, São Paulo, SP, Brazil, \\ e-mail: colariccio@biologico.sp.gov.br
}

(Acepted for publication on 01/10/2003)

Corresponding author: Addolorata Colariccio

COLARICCIO, A., EIRAS, M, CHAVES, A.L.R., HARAKAVA, R. \& CHAGAS, C.M. Tomato chlorotic spot virus in hydroponic-grown lettuce in São Paulo state, Brazil. Fitopatologia Brasileira 29:307-311. 2004.

\begin{abstract}
In the regions of Campinas and Sumaré, São Paulo, Brazil, hidroponically grown crops of Lettuce (Lactuca sativa) cv. Verônica, which showed virus-like symptoms were examined by electron microscope, biological, serological and molecular tests. Pleomorphic, enveloped particles (80-100 nm in diameter) were always detected in these samples. Experimentally inoculated host plants, including lettuce, reacted with tospoviruses-induced symptoms. Some differences were observed in Gomphrena globosa, which reacted by showing local lesions and systemic mosaic. Two isolates of Tomato chlorotic spot virus (TCSV) were identified by DAS-ELISA

and by RT-PCR. The sequencing and alignment of the RT-PCR coat protein amplified fragments have indicated a high degree of homology with the TCSV sequences stored in the GenBank. This is the first report of losses due to a virus from the genus Tospovirus in commercial hydroponic lettuce crops in Brazil. Further epidemiological studies are needed for better understanding the spread of the virus in hydroponic crops, since Tomato spotted wilt virus (TSWV) is reported to spread through the nutritive solution.

Additional keywords: Tospovirus, serology, RT-PCR, sequencing.

\section{RESUMO}

Detecção do Tomato chlorotic spot virus associado a alface em cultivo hidropônico no Estado de São Paulo

Plantas de alface (Lactuca sativa) cv. Verônica cultivadas em sistema hidropônico, provenientes dos municípios de Campinas e Sumaré, SP, apresentando sintomas típicos aos induzidos pelos tospovírus, foram coletadas para análise. Partículas pleomórficas arredondadas e envelopadas (80-100 nm de diâmetro) foram visualizadas ao microscópio eletrônico de transmissão. Plantas indicadoras, incluindo a alface, apresentaram sintomas típicos daqueles induzidos pelos tospovírus. Algumas diferenças foram observadas em Gomphrena globosa, que reagiu com sintomas locais

e sistêmicos. Nestas amostras, identificaram-se dois isolados do Tomato chlorotic spot virus (TCSV) através de DAS-ELISA e seqüenciamento de produtos de DNA do gene da capa protéica amplificados via RT-PCR. O alinhamento das seqüências indicou elevados níveis de homologia com outros isolados de TCSV do GenBank. Este é o primeiro relato de perdas causadas por tospovírus em cultivos comerciais de alface hidropônico, no Brasil. Os aspectos epidemiológicos envolvidos na dispersão do vírus, nestas condições, ainda precisam ser esclarecidos, uma vez que a disseminação de tospovírus através de solução nutritiva tem sido relatada para o Tomato spotted wilt virus (TSWV).
\end{abstract}

Lettuce (Lactuca sativa L.) is an Asian vegetable, which was introduced in Brazil by the Portuguese. Nowadays, it is one of the most appreciated vegetables in the country. Its cultivation reaches a high level of technology including green house, hydroponics and organic cultivation (Filgueira, 2000). Hydroponics as an alternative growing method allows a relatively high numbers of plants per area to be grown durning short time intervals. Although the disease incidence was expected to decrease in lettuce hydroponically grown, the presence of virus-like diseases have been noted in several growing regions of the state of São Paulo.

Lettuce diseases constitute a great problem, since they usually affect leaves, and viruses are especially harmful to commercial lettuce. In Brazil, the first report of the virus from the genus Tospovirus in lettuce was made by Costa \& Forster (1938). At that time, this genus was known as the Tomato spotted wilt virus group and sporadically found on lettuce. Since 1986, however, important outbreaks of diseases have been reported (Moraes et al., 1986).

Currently, the genus Tospovirus, in the Bunyaviridae family (Van Regenmortel et al., 2000), is widely spread throughout. The following species have been reported: Tomato spotted wilt virus (TSWV), Tomato chlorotic spot virus (TCSV), Groundnut ringspot virus (GRSV), Chrysanthemum stem necrosis virus (CSNV), Zucchini lethal chlorotic virus (ZLCV) and Iris yellow spot virus (IYSV) (Pozzer et al., 1999). The identification of species in the genus Tospovirus is made by examining host range, serology, and according to the divergence of amino acids in coat protein (N Protein) (Pozzer et al., 1999). Such species infect plants in 92 botanical families (Van Regenmortel et al., 2000), causing significant losses in several vegetable crops. Infection occurs in lettuce more frequently in 
summer, causing $30 \%$ to $100 \%$ losses (Moraes et al., 1986). In São Paulo, TCSV and GRSV are predominantly transmitted by Frankliniella schultzei Trybom. They were recently reported in field-cultivated lettuce where they did not induce significant losses (Colariccio et al., 2001a, 2001b; Chaves et al., 2001).

The present work deals with the serological identification and molecular characterization of two TCSV isolates from hydroponically grown lettuce cv. Verônica collected in the municipalities of Campinas and Sumaré, São Paulo, Brazil.

The lettuce from which the virus isolates were obtained showed stunted plant growth, virus-like leaf symptoms of mosaic, necrosis, and chlorotic and necrotic ringspot.

Naturally-diseased lettuce leaf fragments were ground in cold (ca. $\left.4^{\circ} \mathrm{C}\right) 0.5 \%$ sodium sulphite and the inoculum rubbed on previously carborundum-dusted leaves of the healthy indicator host plants Chenopodium amaranticolor Coste \& Reyn, Gomphrena globosa L., Lycopersicon esculentum Mill., Nicotiana glutinosa L., N. tabacum L. ('Samsun NN' 'Turkish' and 'White Burley'), Petunia hybrida Vilm. and lettuce.

Infected lettuce leaf extracts were negatively stained with $2 \%$ uranyl acetate and observed under a Philips EM 208 electron microscope, according to Eiras et al. (2002).

The identification of the Tospovirus species infecting lettuce samples was performed by DAS-ELISA (Colariccio $e t$ al., 2001a, 2001b), using polyclonal antibodies against coat protein from TSWV, TCSV, GRSV and CSNV. Absorbance $\left(\mathrm{A}_{405 \mathrm{~nm}}\right)$ evaluations were made after the addition of the substratum ( $p$-nitrophenilphosphate), using a Microplate reader 3550-UV (Bio-Rad). The results were analyzed based on the ratio between the mean of three readings in the infected samples and those in the healthy ones $(\mathrm{I} / \mathrm{H})$.

Extraction of total RNAs was performed according to Eiras et al. (2002), from $1 \mathrm{~g}$ of infected lettuce leaves. The complementary DNA (cDNA) strands were synthesized by mixing $1 \mu \mathrm{g}$ of total RNAs with the "Preamplification System First Strand cDNA Synthesis" (Gibco BRL), according to the manufacturer's instructions, and using the primer named BR60 (5' AGAGCAATTGTGTCA 3'), (Eiras et al., 2002). PCR was carried out using $10 \mu \mathrm{l}$ of the cDNA strands, $10 \mathrm{ng} / \mu \mathrm{l}$ of the BR60 and BR65 (5'ATCAAGCCTTCTGAAAGTTCAT 3') primers, one unit of Taq DNA polymerase, $1 \mu 1$ of the deoxynucleotide mixture $(0.03 \mathrm{M})$ and $5 \mu \mathrm{l}$ of enzyme buffer. Samples were then placed in a PTC-100 MJ-Research thermocycler. After an initial heating at $94{ }^{\circ} \mathrm{C}$ for $5 \mathrm{~min}$, the amplification was reached by 30 cycles of $94{ }^{\circ} \mathrm{C}$ for $1 \mathrm{~min}$ followed by $48{ }^{\circ} \mathrm{C}$ for $1 \mathrm{~min}, 72{ }^{\circ} \mathrm{C}$ for $1 \mathrm{~min}$ and by a final heating at $72^{\circ} \mathrm{C}$ for the extention. The amplified DNA fragments were subjected to electrophoresis in $1 \%$ agarose gel, stained with ethydium bromide $(0.01 \%)$ and visualized in a UV translluminator (Eiras et al., 2002).

Amplified RT-PCR products were purified from the agarose gel by the Concert Rapid Gel Extraction System (Life Technologies) kit, cloned into the pGEM-T vector (Promega) and used for transforming competent Escherichia coli cells $($ DH5- $\alpha)$. The procedures used were those of Sambrook et al.(1989), according to the supplier's directions.
Amplified products were sequenced by the terminal chain reaction technique, using the automatic $\mathrm{ABI} 377$ sequencer and the ABI Prism Big Dye Terminator Cycle Sequencing Ready Reaction kit - Ampli Taq DNA polymerase, FS (Perkin Elmer) according to the manufacturer's instructions. The alignment of the obtained sequences was performed with the Sequencer 3.1 program (Gene Codes Corporation), and comparisons with sequences from the GenBank were performed through the BLAST program of the National Center for Biotechnology Information - NCBI. Multiple alignments were done using CLUSTAL $\mathrm{X}$ and cluster analysis was done using TreeView 1.5 .

Inoculated indicator host plants reacted with the same symptoms for both Campinas and Sumaré virus isolates. Petunia hybrida and C. amaranticolor reacted with local necrotic rings. Systemic mosaic, crinkle of younger leaves and necrosis were noted on L. esculentum, $N$. debneyi, $N$. glutinosa and $N$. tabacum; local necrotic points and whitish mosaic were found in G. globosa, while mosaic, necrosis and stunting occurred in lettuce. These host responses are typical for those caused by tospoviruses, except for the systemic infection on $G$. globosa.

Electron microscope observations showed consistent presence of enveloped, rounded and pleomorphic particles with 80-100 nm in diameter, comparable to Tospovirus particles, in extracts of infected lettuce leaves.

By means of DAS-ELISA, using the antisera to the main tospoviruses occurring in Brazil, TCSV was identified in the lettuce samples. Test samples were positive when the absorbance values from infected plant extracts were threefold higher than those from healthy plant ones, corresponding to 0.850 and 0.960 for samples from Campinas (TCSV-C) and Sumaré (TCSV-S), respectively. No reaction was obtained with the remaining antisera.

The TCSV has also been serologically detected in dual infection with GRSV in hidroponic lettuce in the municipalities of Amparo and Itatiba, São Paulo and, recently, TCSV was identified as having infected hydroponic endive (Cichorium endivia L.) in areas of Vargem Grande Paulista, SP, growing areas (Colariccio et al., 2001a). A recent survey indicated that TCSV has also been prevalent in different vegetable growing areas in the state of São Paulo and that GRSV is prevalent in lettuce in the São Francisco River Valley, in the state of Pernambuco (Colaricio et al., 2001b). Both TCSV and GRSV, which are efficiently transmitted by the thrips species $F$. occidentalis Pergande and F.schultzei (Wijkamp et al., 1995; Borbon \& Garcia, 1996), are prevalent in tropical and subtropical regions (Wijkamp et al., 1995) and have been reported only in Brazil, South Africa and Argentina (Dewey et al., 1996).

The DNA fragments with 442 bp were amplified by RTPCR using the BR60 and BR65 oligonucleotides (Figure 1). No amplified products were obtained from healthy plants. The two oligonucleotides align with S RNA in the 3' end untranslated region and in the coat protein gene ( $\mathrm{N}$ gene), respectively, and permit amplification of at least five different tospovirus species, 
Tomato chlorotic spot virus in hydroponic-grown lettuce in...

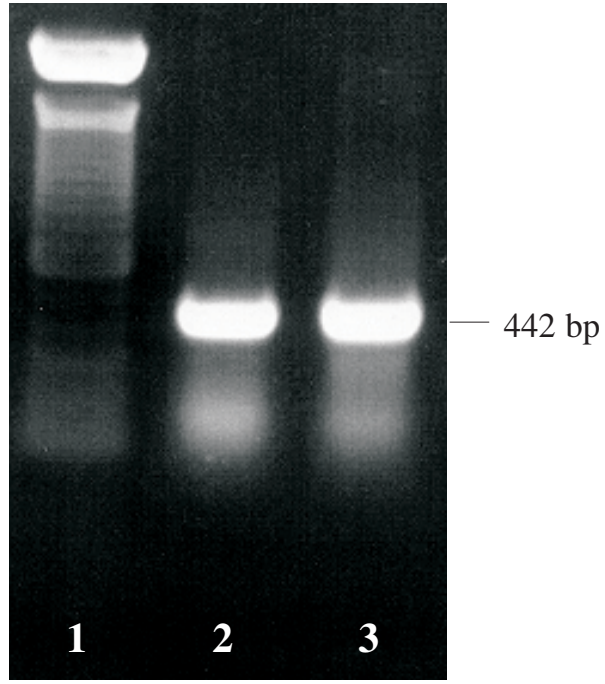

FIG. 1 - Results of RT-PCR for total RNAs samples from infected lettuce (Lactuca sativa), amplified with BR60 and BR65 primers. Lane 1 corresponds to $100 \mathrm{bp}$ DNA ladder (Gibco BRL), lanes 2 and 3 correspond to Campinas and Sumaré TCSV isolates, respectively.

ie TSWV, TCSV, GRSV, INSV and CSNV (Eiras et al., 2002). The sequencing and alignment of the RT-PCR amplified fragments have indicated a high degree of similarity with the sequences of TCSV stored in the GenBank (Figure 2; Table 1). The nucleotide sequences comparison between TCSV-S and TCSV-C showed few differences with $99 \%$ similarity, presenting an identical deduced aminoacid sequence (Figure 2, Table 1). The dendrogram that resulted from the simultaneous alignment and phylogeny program CLUSTAL-X 1.8, graphically illustrated using TreeView 1.5 , based on the tospoviruses nucleotides coat protein sequences, showed that TCSV-C and TCSV-S belong to a cluster formed by other TCSV isolates (Figure 3). The high nucleotide similarity and the identical amino acids sequence between the two TCSV lettuce

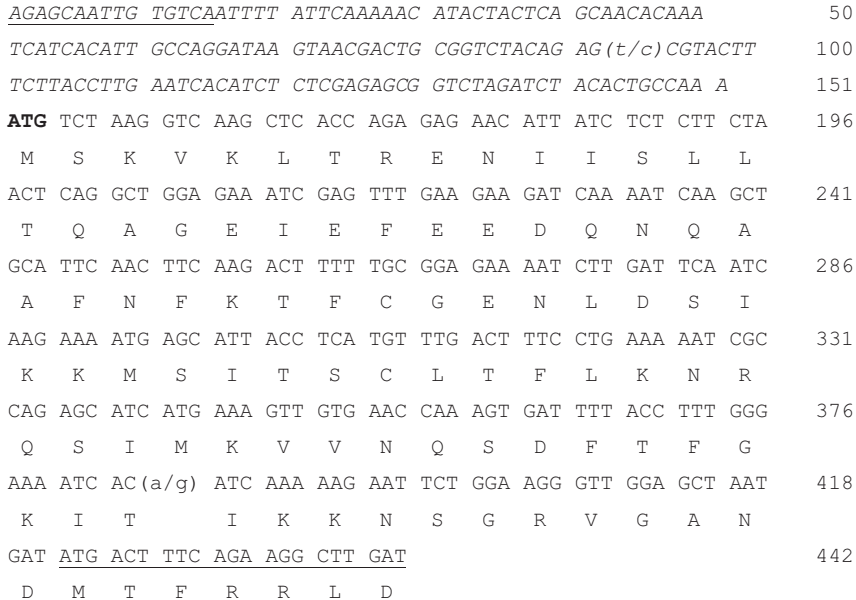

FIG. 2 - Nucleotides (above) and deduced amino acids (below) of the Tomato chlorotic spot virus (TCSV-C) and TCSV-S hydroponic lettuce (Lactuca sativa) isolates, from Campinas and Sumaré, respectively, amplified by RT-PCR. The primers BR60 and BR65 are underlined. The start codon (ATG) of the coat protein gene is shown in bold at the position 152 . The untranslated region is indicated in italic. Differences on nucleotides between the two lettuce isolates, TCSV-C and TCSV-S, are indicated, respectively, in parenthesis. No amino acids changes were observed between the two isolates. The nucleotides are numbered from the $5^{\prime}$ end viral strand.

isolates may represent an ecological adaptation factor, probably related to their adaptation to different hosts and vectors (Eiras et al., 2002). The two TCSV lettuce isolates were more closely related to the TCSV isolate from Minas Gerais, presenting an identical amino acids sequence among them, and presenting a high degree of homology with the TCSV-J (Eiras et al., 2002) and BR03 isolates (Figure 3). On the other hand, the TCSV$\mathrm{AR}$, from Argentina, presented significant amino acids changes (Figure 3) and remains in an isolate branch in the dendrogram (Figure 4), which may be related to its geographical distance.

TABLE 1 - Comparison (similarity in percentage) among nucleotides sequence (above the diagonal) and translated amino acids (below the diagonal) of the Tomato chlorotic spot virus (TCSV) lettuce (Lactuca sativa) isolates coat protein with other Tospovirus sequences of the Genbank*

\begin{tabular}{lcccccccccc}
\hline \hline Species & TCSKC $^{\mathbf{1}}$ & TCSVS $^{\mathbf{2}}$ & TCSVJ $^{\mathbf{3}}$ & TCSV $^{\mathbf{4}}$ & TCSV $^{\mathbf{5}}$ & TCSV $^{\mathbf{6}}$ & GRSV $^{\mathbf{7}}$ & TSWV $^{\mathbf{8}}$ & ZLCV $^{\mathbf{9}}$ & CSNV $^{\mathbf{1 0}}$ \\
\hline TCSVC & & 99 & 99 & 97 & 99 & 95 & 84 & 80 & 85 & 84 \\
TCSVS $^{2}$ & 100 & & 99 & 98 & 99 & 95 & 84 & 80 & 85 & 83 \\
TCSVJ $^{3}$ & 99 & 99 & - & 99 & 96 & 92 & 81 & 78 & 74 & 73 \\
TCSV $^{4}$ & 98 & 98 & 98 & - & 96 & 92 & 81 & 79 & 74 & 74 \\
TCSV $^{5}$ & 100 & 100 & 95 & 96 & - & 95 & 82 & 78 & 74 & 74 \\
TCSV $^{6}$ & 95 & 95 & 93 & 94 & 95 & - & 81 & 78 & 74 & 74 \\
GRSV $^{7}$ & 84 & 84 & 84 & 83 & 87 & 85 & - & 78 & 75 & 74 \\
TSWV $^{8}$ & 78 & 78 & 78 & 77 & 80 & 79 & 79 & - & 74 & 76 \\
ZLCV $^{9}$ & 73 & 73 & 72 & 72 & 75 & 74 & 76 & 74 & - & 77 \\
CSNV $^{10}$ & 74 & 74 & 74 & 73 & 75 & 74 & 74 & 77 & 80 & - \\
\hline
\end{tabular}

1. Tomato chlorotic spot virus (TCSV-C) lettuce (Lactuca sativa) isolate from Campinas, SP (hydroponic); 2. Tomato chlorotic spot virus (TCSVS) lettuce isolate from Sumaré, SP (hydroponic); 3. TCSV-J Solanum gilo isolate from Paraíba Valley, SP (AF413110); 4. TCSV (BR03) tomato isolate (S54325); 5. TCSV isolate from Minas Gerais (AF282982); 6. TCSV isolate from Argentina (U49709); 7. Groundnut ringspot virus GRSV (AF25271); 8. Tomato spotted wilt virus - TSWV (AB038341); 9. Zucchini lethal chlorosis virus - ZLCV (AF067069); 10. Chrysanthemum stem necrosis virus - CSNV (AF067068). *The GenBank accession numbers are indicated in parenthesis. 
A. Colariccio et al.

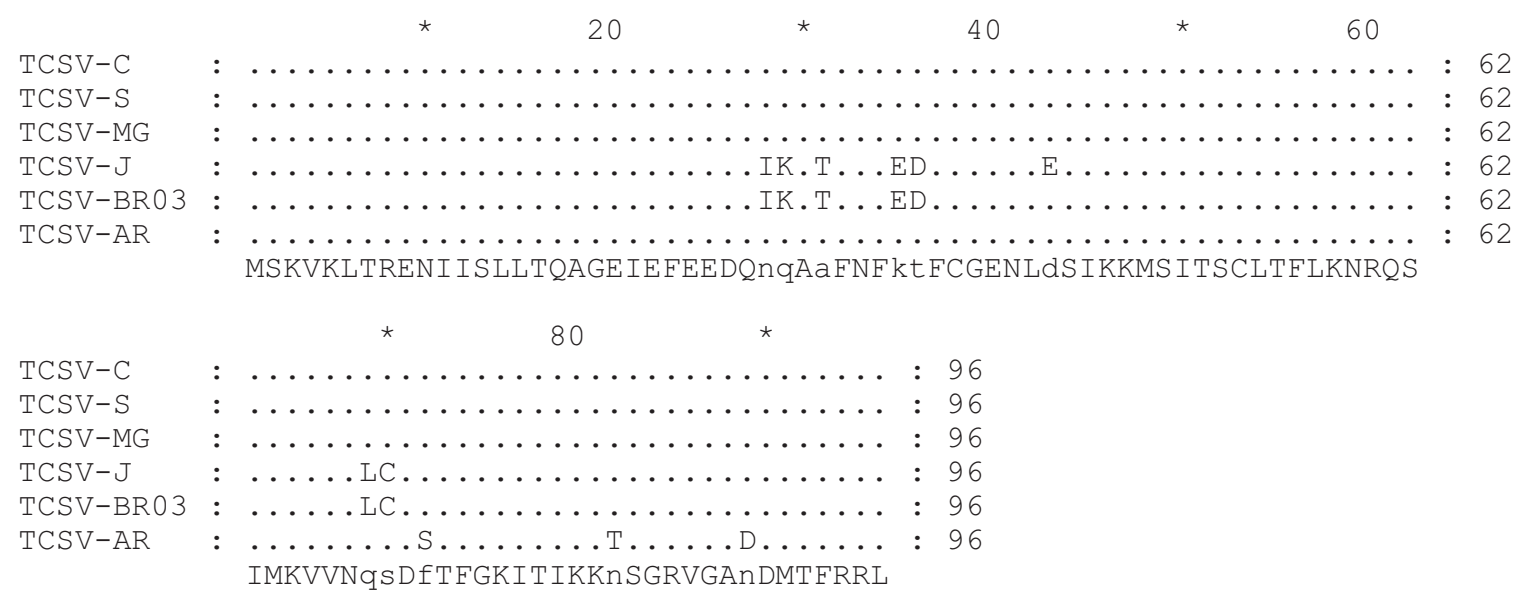

FIG. 3 - Alignment of the deduced coat protein aminoacid sequences of Tomato chlorotic spot virus (TCSV) characterized in this work (TCSV-C and TCSV-S isolated from infected hydroponic lettuce (Lactuca sativa) from Campinas and Sumaré, respectively) with other TCSV isolates. The consensus sequence is shown at the bottom, and the amino acids that differ from the consensus sequence are indicated for each TCSV isolate. GenBank accession numbers are as described in Table 2.

Using molecular studies, different tospovirus species have been identified and characterized in Brazil (Pozzer et al., 1999), which constitute a limiting production factor for vegetable crops in the country, mostly Asteraceae and Solanaceae family (Colariccio et al., 2001a, 2001b; Lima et al., 2000).

In the present work two TCSV isolates were characterized from hydroponic lettuce under field cultivation in Campinas and Sumaré, where the field crop covers from 25 to 200 ha and from 5 to 25 ha, respectively (www.cati.sp.gov.br). The TCSV is the main tospovirus in the state of São Paulo where it is harmful to different crops, but especially to vegetables (Colariccio et al., 2001b).

The identification and characterization of TCSV on hydroponically grown lettuce may be important for future studies in breeding programs. However, data concerning behavior of different lettuce cultivars towards tospovirus species are not consistent so far. Breeding cultivars for high resistance levels to TCSV seems to be the best control strategy, since thrips control has not been efficient. Lettuce was mostly grown in Brazil during autumn and winter, but has had its cycle extended by breeders who developed cultivars for spring and summer cropping (Filgueira, 2000); thus, the lettuce crops remain exposed throughout the year to vectors and tospovirus sources. In this context, tospovirus susceptible cultures, including vegetables and ornamentals, represent important sources for spreading these viruses. Eradication of weeds and volunteer growth close to hydroponic lettuce, in association with other cultural practices, could minimize and prevent attacks of tospoviruses. Further epidemiological studies for better understanding the spread of tospovirus into hydroponic crops are needed, since TSWV has been reported to be disseminated through nutritive solutions (Paludan, 1985).

Besides cultural practices, it is of pivotal importance

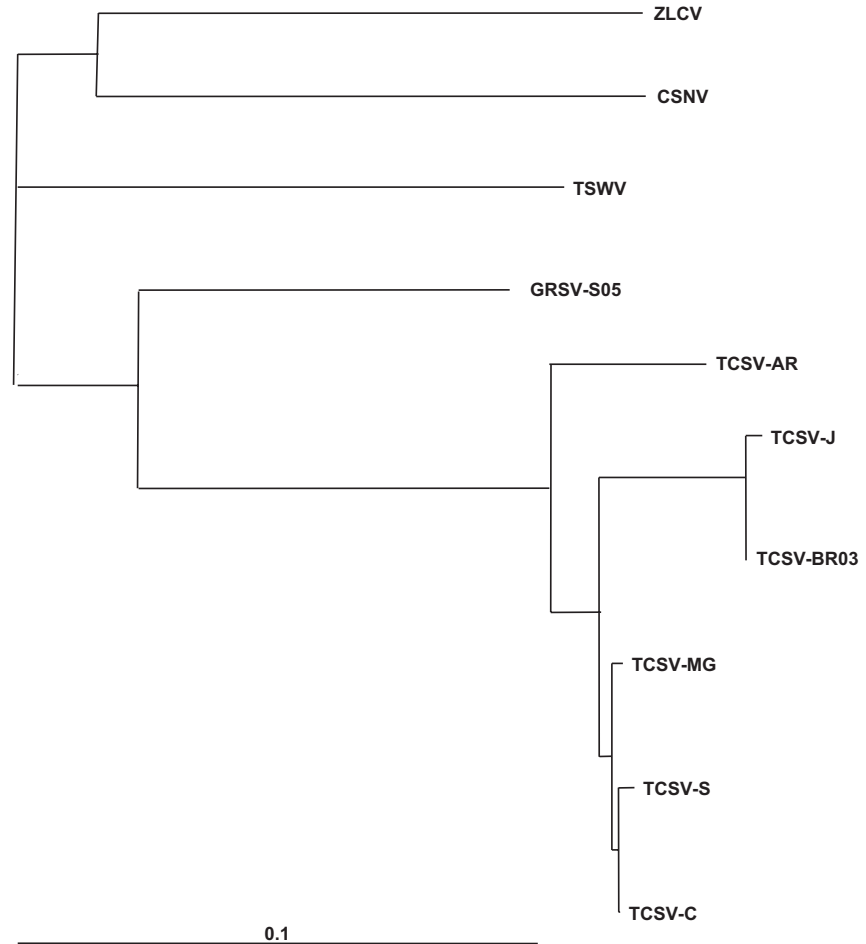

FIG. 4 - Dendrogram of the tospovirus coat protein nucleotides sequences, constructed using the simultaneous alignment and phylogeny program CLUSTAL-X 1.8 and graphically illustrated using TreeView 1.5. The scale bar indicates 0.1 substitution per site. Accession numbers are as described in Table 2.

that new lettuce lines be introduced into breeding programs targeting tospovirus resistance. Losses due to tospoviruses have been reported to reach $100 \%$ in lettuce field crops (Moraes et al., 1986). Although losses of about $40 \%$ have been observed 
Tomato chlorotic spot virus in hydroponic-grown lettuce in...

in hydroponic lettuce (Colariccio, personal communication), further studies are needed to evaluate the potential threat of tospoviruses to Brazilian hydroponically-grown lettuce.

\section{ACKNOWLEDGMENTS}

The authors are indebted to Dr. Antônio Carlos de Ávila (Embrapa-Hortaliças) for providing antisera and to Mr. Sérgio Vianna (Instituto Biológico) for the photographic assistance.

\section{LITERATURE CITED}

BORBON, C.M. \& GRACIA, O. Frankliniella schultzei (Tribom), eficiente vector de Groundnut ringspot virus (GRSV) en cultivo de lechuga en Mendoza, Argentina. Fitopatologia Brasileira 21:423. 1996 (Abstract).

CHAVES, A.L.R., EIRAS, M., COLARICCIO, A., MOREIRA, S.R. \& CHAGAS, C.M. Detecção do Groundnut ringspot tospovirus em alface e tomateiro no Estado de São Paulo. Summa Phytopathologica 27:50-53. 2001.

COLARICCIO, A., CHAVES, A.L.R., EIRAS, M. \& CHAGAS, C.M. Identificação do Tomato chlorotic spot tospovirus em escarola (Cichorium endivia L.). Summa Phytopathologica 27:325-327. 2001a.

COLARICCIO, A., EIRAS, M., CHAVES, A.L.R., ROGGERO, P. \& CHAGAS, C.M. Diversidade de tospovírus em olerícolas no Estado de São Paulo. Summa Phytopathologica 27:177-182. 2001b.

COSTA, A.S. \& FORSTER, R. A transmissão mecânica de viracabeça por fricção com suco. Revista de Agricultura 13:249-262. 1938.

DEWEY, R.A., SEMORILE, L.C. \& GRAU, O. Detection of Tospovirus species by RT-PCR of the N-gene and restriction enzyme digestions of the products. Journal of Virological Methods 56:1926. 1996.
EIRAS, M., CHAVES, A.L.R., COLARICCIO, A., HARAKAVA, R., ARAUJO, J. \& CHAGAS, C.M. Caracterização do Tomato chlorotic spot virus isolado de jiló no Vale do Paraíba, Estado de São Paulo. Fitopatologia Brasileira 27:285-291. 2002.

FILGUEIRA, F.A.R. Novo Manual de Olericultura: agrotecnologia moderna na produção e comercialização de hortaliças. Viçosa. Universidade Federal de Viçosa, MG, Editora UFV. 2000.

LIMA, M.F., DE ÁVILA, A.C., RESENDE, R.O. \& NAGATA, T. Levantamento e identificação de espécies de tospovírus em tomateiro e pimentão no sub-médio do Vale do São Francisco e no Distrito Federal. Summa Phytopathologica 26:205-210. 2000.

MORAES, G.J., WANDERLY, L.J. \& COSTA, A.S. Surto de viracabeça na cultura de alface em Pernambuco. Horticultura Brasileira 6:24-25. 1986.

PALUDAN, N. Spread of viruses by recirculated nutrient solutions in soilless cultures. Tijdschr. Plantenziekten 89:467-474. 1985.

POZZER, L., BEZERRA, I.C., KORMELINK, R., PRINS, M., PETERS, D., RESENDE, R.O. \& DE ÁVILA, A.C. Characterization of a Tospovirus isolate of Iris yellow spot virus associated with a disease in onion fields in Brazil. Plant Disease 83:345-350. 1999.

SAMBROOK, J., FRITSCH, E.F. \& MANIATIS, T. Molecular Cloning: A laboratory manual. $2^{\text {nd }}$ ed. New York, Cold Spring Harbor Laboratory Press. 1989.

VAN REGENMORTEL, M.H.V., FAUQUET, C.M., BISHOP, D.H.L., CARSTENS, E.B., ESTES, M.K., LEMON, S.M., MANILOFF, J., MAYO, M.A., McGEOCH, D.J., PRINGLE, C.R. \& WICKNER, R.B. Virus Taxonomy Classification and Nomenclature of Viruses. Seventh Report of the International Committee on Taxonomy of Viruses. Academic Press, California, USA. 2000.

WIJKAMP, I., ALMARZA, N., GOLDBACH, R. \& PETERS, D. Distinct levels of specificity in thrips transmission of tospoviruses. Phytopathology 85:1069-1074. 1995. 